\title{
Transformations of Transcendental Philosophy: Wolff, Kant, and Hegel
}

\author{
Karin de Boer
}

\section{Introduction}

Kant's philosophy is generally known as transcendental philosophy or transcendental idealism, terms often thought to describe the inquiry into the subjective conditions of empirical knowledge carried out in the Critique of Pure Reason. On this conception of transcendental philosophy Kant is seen to pursue a project very different from both Wolffian metaphysics and Hegelian speculative science. This view is confirmed by scholars who compare Kant's conception of transcendental philosophy to the Scholastics' conception of 'transcendentals' such as unity, truth, and perfection. On their account, there remains a puzzling gap between, on the one hand, the scholastic conception of the most general determinations of all beings and, on the other hand, Kant's investigation into the conditions of possibility of experience. ${ }^{1}$

In this article I want to challenge this common view of Kant's transcendental philosophy for two reasons. The first reason concerns the question of how the Critique of Pure Reason itself should be read. I take the view that in the first Critique Kant's primary aim is to determine the conditions of synthetic a priori knowledge rather than to identify the a priori conditions of empirical knowledge. ${ }^{2}$ Since metaphysics was traditionally considered to be the discipline that possessed a priori knowledge of things, this view makes good sense of Kant's presentation of the Critique of Pure Reason as a work intended to transform metaphysics into a science. ${ }^{3}$ In this article I hope to clarify the nature of this transformation by determining the elements which Kant's transcendental philosophy has in common with Wolff's ontology, as well as the respects in which Kant turns against Wolff. I thus hope to solve some of the riddles posed by Kant's use of the term 'transcendental philosophy' in the Critique of Pure Reason.

My second reason for questioning the common conception of transcendental philosophy concerns Hegel's indebtedness to Kant. Commentators on the Science of Logic who take Hegel's relation to Kant into account usually assume that Kant's transcendental philosophy has very little to do with Wolffian metaphysics. ${ }^{4}$ Accordingly, Hegel's Logic is considered to be either a metaphysical system that is opposed to Kant's alleged subjectivism or a non-metaphysical form of logic deeply indebted to this very 


\section{Karin de Boer}

subjectivism. Bracketing the issue of Kant's alleged subjectivism, I hope to show that the opposition between metaphysical and non-metaphysical readings of Hegel is a false one. In line with non-metaphysical readings, I believe that Hegel was more deeply indebted to Kant than he generally admits. In line with metaphysical readings, on the other hand, I hold that this debt concerns Kant's conception of metaphysics rather than the subjectivism commonly attributed to Kant — not least by Hegel himself. ${ }^{5}$

I will argue that Kant's understanding of transcendental philosophy provides an important clue as to how we might clarify the deep affinity, as well as the decisive differences, between the conceptions of metaphysics elaborated by Wolff and Hegel. Central to this argument is an analysis of Kant's conception of transcendental cognition, a conception that allows him, first, to differentiate between transcendental critique and transcendental philosophy and, second, to interpret the disciplines that used to be called scientia transcendens or ontology as well as the first part of his own projected metaphysical system as different guises of the latter. I want to begin however by considering briefly Hegel's own ambivalent assessment of Kant, for his work is undoubtedly one of the chief sources of the distorted picture of what Kant meant by transcendental philosophy.

\section{Hegel on Kant}

According to Hinske, already around 1800 the term 'transcendental' was generally used to denote Kant's critical philosophy alone. ${ }^{6}$ This is also true of Hegel, who, in his Lectures on the History of Philosophy and other texts considers Kant's transcendental philosophy merely to trace back the categories — qua determinations of thought — to their subjective origin:

Kant defines transcendental philosophy not as a philosophy that by means of categories passes beyond its sphere, but as a philosophy which points out the sources of that which can become transcendent. This expression merely refers to the sources of such determinations, that is, to consciousness. ... Thus we do not desire to consider the categories in their objective sense, but insofar as thought is the source of such synthetic relations; the transcendental consists in making manifest such determinations in subjective thought (LHP III, 337-338/431, translation modified). ${ }^{7}$

In many other texts, Hegel portrays Kant in a similar way, as someone who merely investigated the subjective origin of a priori knowledge (cf. L I, 59/62). Yet there are reasons to doubt Hegel's sincerity in this regard. In the Preface to the Science of Logic he distinguishes between the true core of Kant's philosophy and the doctrine accepted by the majority of his readers. According to Hegel, this 'exoteric' doctrine states that the 
understanding cannot transcend the realm of experience. ${ }^{8}$ It is not quite clear, however, what Hegel regards as the esoteric core of Kant's philosophy. On some occasions he refers to Kant's investigation of consciousness as a necessary stage in a process the end of which is reached in the Logic itself. This end is said to consist in a system exclusively concerned with the determinations of thought themselves rather than with their subjective source:

But in order for philosophy to make any real progress, it was necessary that the interest of thinking should be drawn to a consideration of the ego, of consciousness as such ..., so that in this way the cognition of the infinite form, that is, of the concept, would be introduced. But in order that this cognition may be reached, that form has still to be relieved of the finite determinateness in which it is ego, or consciousness. The form, when thus thought out in its purity, will have within itself the capacity to determine itself, that is, to give itself a content, and that a necessarily explicated content — in the form of a system of determinations of thought (L I, 61/63).

Clearly, this system differs from the Critique of Pure Reason in that it disregards the subjective origin of the categories as well as the kind of objects to which they can be applied. Yet toward the end of the Logic, Hegel admits that it was Kant who initiated this examination of the determinations of thought in and for themselves:

It is an infinite merit of the Kantian philosophy ... to have given the impetus to the restoration of logic and dialectic in the sense of the examination of the determinations of thought in and for themselves. ... [T] hese determinations are in fact the sole thing that matters; they are the true subject and content of reason, and anything else that one understands by subject matter and content in distinction from them has value only through them and in them (L II, 559-560/833).

Thus, Hegel implicitly distinguishes between Kant's examination of the categories in and for themselves and, on the other hand, his alleged assumption that these categories constitute determinations of the subject alone. Apparently he saw it as his task to liberate Kant's philosophy from this latter assumption. Now I agree with Hegel's distinction of these two strands in Kant's Critique of Pure Reason. I hold that he was wrong, however, to denote the subjective strand of the Critique of Pure Reason as transcendental philosophy and to present this strand as Kant's principal aim. This characterisation is in line with his almost complete silence concerning Kant's attempt to transform metaphysics into a science, a task that, in my view, does not necessarily entail subjectivism. In order to 


\section{Karin de Boer}

understand the thrust of this transformation it is necessary to consider the way in which Wolff defined the task of ontology.

\section{Wolff's Conception of Ontology}

The intricate history of the many conceptions of metaphysics, ontology, and transcendental philosophy developed in the scholastic tradition and in the post-Cartesian school philosophy of the seventeenth and eighteenth centuries exceeds the scope of this article. It is sufficient to note that metaphysicians became increasingly aware of the necessity to make a clear-cut distinction between a form of metaphysics concerned with the determinations of beings qua beings and, on the other hand, a form of metaphysics devoted to specific beings such as the soul or God. ${ }^{9}$ During the seventeenth century, these two branches of metaphysics became known as general and special metaphysics. Emancipating itself from the traditional theological orientation of metaphysics, general metaphysics increasingly geared itself toward the challenges posed by the modern sciences. Its primary task came to consist in a systematic investigation of the conceptual determinations that can be predicated of all beings, determinations which, as such, are necessarily presupposed in the other sciences. This is the conception of first philosophy that we also find in Wolff's philosophy. Wolff uses the term 'ontology' - despised by the Cartesians - to refer to this foundational discipline:

Some characteristics are common to all beings; these are predicated of souls as well as physical things, be they natural or produced. The part of philosophy that treats of beings as such and the general properties of beings is called ontology. ... Such general concepts include the concept of essence, existence, property, mode, necessity, contingency, place, time, ... etc. Neither psychology nor physics can adequately explain these concepts, because we, in these sciences as well as in all other parts of philosophy, require these concepts and the principles derived from them (DP \$73, my emphasis). ${ }^{10}$

The fact that ontology is said to concern all beings should not be taken to imply that it deals with actual beings themselves - quite the contrary. Wolff considered ontology to investigate merely the conceptual determinations that can be predicated of any being, that is, the concepts which allow us to determine particular beings in particular respects. Thus, within physics, concepts such as 'composite' and 'cause' are predicated of material things. Any further determination of these beings presupposes these ontological predications. Wolff maintains, moreover, that philosophy as such is the science of beings insofar as 
they are possible. ${ }^{11}$ This also indicates that ontology, as a philosophical discipline, is not concerned with actual beings.

Baumgarten's conception of ontology does not significantly differ from Wolff's. In his Metaphysics he defines ontology, as the first part of metaphysics, as 'the science of the more general predicates of a being', predicates which constitute the 'first principles of human cognition'.12 Clearly, Wolff's and Baumgarten's definitions of ontology contain two elements. On the one hand, they conceived of ontology as a reflection on the basic principles of human knowledge. On the other hand, they assumed that these principles could be used to achieve knowledge of material things as well as of immaterial things such as the soul and God. Seen from a Wolffian perspective, there is no need to separate these two elements. For Kant, by contrast, it became crucial to distinguish these two strands of the classical conception of ontology. As I will argue in the next section, Kant primarily came to renounce Wolff's assumption that a principle such as causality can be applied indiscriminately to material beings such as billiard balls and an immaterial being such as God. For Kant, the term 'ontology' therefore became an inadequate description of the discipline concerned with the first principles of human cognition.

\section{Kant's Conception of Transcendental Philosophy}

During the seventeenth century the discipline called ontology also became known as scientia transcendentalis, a term that goes back to Duns Scotus' conception of metaphysics as scientia transcendens. ${ }^{13}$ That is why Kant already in his Latin Physical Monadology (1756) could identify metaphysics and transcendental philosophy, apparently assuming that his readers were familiar with the latter title:

Metaphysics, therefore, which many say may be properly absent from physics, is, in fact, its only support; it alone provides illumination. For bodies consist of parts; it is certainly of no little importance that it be clearly established of which parts, and in what way they are combined together. ... But how, in this business, can metaphysics be married to geometry, when it seems easier to mate griffins with horses than to unite transcendental philosophy with geometry? (PM 475, my emphasis). ${ }^{14}$

The context makes it clear that Kant here uses the term 'transcendental philosophy' to refer to general metaphysics rather than special metaphysics or metaphysics as such. In line with Wolff's conception of ontology, moreover, Kant clearly considers this metaphysics to be concerned with the first principles of human cognition.

Evidently, this early passage does not allow us to draw conclusions as to the meaning of the term 'transcendental philosophy' in the Critique of Pure Reason. Yet the definitions of transcendental cognition and transcendental philosophy in this work 


\section{Karin de Boer}

suggest a close link between Kant's conception of transcendental philosophy and ontology as conceived by Wolff. None of these definitions includes a reference to conditions of possibility of experience. Thus, in the Introduction to the first edition of the Critique, Kant defines transcendental cognition as a form of cognition that is not so much concerned with objects as with our a priori concepts of objects as such. Transcendental philosophy is subsequently defined as the system containing the totality of these concepts:

[Definition 1] I call all cognition transcendental that is occupied not so much with objects but rather with our a priori concepts of objects as such. A system of such concepts would be called transcendental philosophy (CPR, A1112). ${ }^{15}$

Kant here might seem to oppose transcendental philosophy to the discipline that used to be called ontology. I have argued, however, that Wolffian ontology deals with the conceptual determinations of any being - from which the other sciences draw their principles - rather than with actual beings. Considered in this way, Kant's conception of transcendental philosophy and Wolff's conception of ontology have much more in common than may have appeared at first sight. Accordingly, I take Kant's introductory definition to abstract from the difference between pre-critical and critical instantiations of transcendental philosophy.

In the Doctrine of Method, Kant comes close to identifying transcendental philosophy and ontology. In the Architectonic of Pure Reason he sketches out the structure of the metaphysical system he intended to elaborate on the basis of the propaedeutic task carried out in the Critique. Kant here defines metaphysics as the form of philosophy which offers a systematic account of our a priori knowledge, that is, of the pure concepts and a priori principles which allow us to achieve knowledge of anything at all (A845/B873). In line with the classical distinction between general and special metaphysics, Kant distinguishes two branches of metaphysics. The first he calls transcendental philosophy. It is distinguished from the discipline called rational physiology (formerly called special metaphysics) in that it does not presuppose given objects, but investigates the concepts and principles that pertain to objects as such. Transcendental philosophy achieves this task by examining the understanding and reason, that is, the faculties which produce these concepts and principles. This is, according to Kant, what transcendental philosophy has in common with ontology:

[Definition 2] Metaphysics is the kind of philosophy that is to present [a priori] cognition in this systematic unity. ... Metaphysics in a narrower sense consists of transcendental philosophy and the physiology of pure reason. The former considers only the understanding and reason itself in a system 
of all concepts and principles that are related to objects as such, without assuming objects that would be given (Ontologia); the latter considers nature, i.e., the sum total of given objects (whether they are given by the senses or, if one will, by another kind of intuition), and is therefore physiology (though only rationalis) (A845/B837, my emphasis). ${ }^{16}$

In line with the first definition, Kant here conceives of transcendental philosophy as a discipline concerned not so much with actual objects as with the concepts and principles that allow us to achieve knowledge of objects at all. Contrary to the first definition, this passage explicitly states that this discipline, as the first part of metaphysics, used to be called ontology. Kant here affirms the similarity between his position and Wolff's without a qualm. Yet elsewhere in the Critique — one might object — Kant famously maintains that his analysis of pure understanding replaces ontology:

[The principles of the Transcendental Analytic] are merely principles of the exposition of appearances, and the proud name of an ontology, which presumes to offer synthetic a priori cognitions of things in general in a systematic doctrine (e.g. the principle of causality), must give way to the modest one of a mere analytic of the pure understanding (A247/B303, my emphasis).

This passage is often cited to argue that Kant considered transcendental philosophy to be something completely different from ontology. However, one discipline can be said to replace another only if they share some common ground. Seen from Kant's vantage point, his analytic of pure understanding and ontology both investigate our synthetic a priori cognitions, that is, the concepts and principles which allow us to turn something into an object of knowledge at all. Clearly, Kant does not share Wolff's assumption that these concepts can be attributed to all things, whether material or immaterial, finite or infinite. Yet this does not imply that he opposes the modern, epistemological strand of Wolffian ontology. As I see it, Kant uses the term 'transcendental philosophy' primarily as a formal characterisation of the part of philosophy devoted to the first principles of human cognition, regardless of its specific elaboration. On this account, transcendental philosophy refers to any metaphysics that treats the most basic pure concepts and their corresponding a priori principles, and this without assuming the existence of given objects. This formal definition fits both Wolffian ontology and the reformed transcendental philosophy that Kant intended to elaborate on the basis of the Critique.

If we accept the proposition that Kant employs this formal conception of transcendental philosophy, then his reference to the 'transcendental philosophy of the ancients' (B113) also makes perfect sense. In my opinion, this expression simply refers to the scholastic elaboration of that part of philosophy which is concerned with the first 


\section{Karin de Boer}

principles of human cognition, a form of transcendental philosophy distinguished from later versions by the fact that it devoted a special part to general predicates such as unity, truth, and perfection (the so-called transcendentia). Considered in this way, transcendental philosophy is a formal concept that contains at least three determinations:

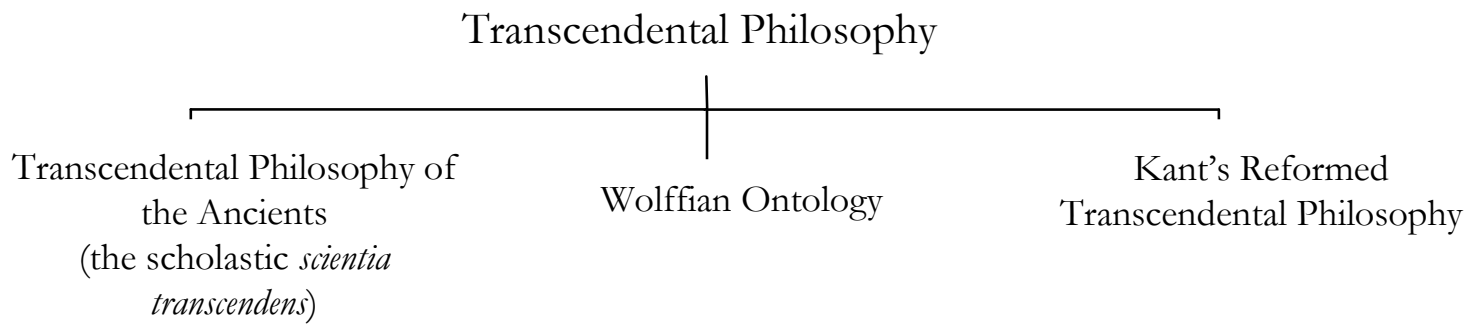

Each of the definitions of transcendental philosophy offered in the Critique of Pure Reason can be read in the formal manner I propose. This also holds of the following one:

[Definition 3] And here I make a remark the import of which extends to all of the following considerations, ... namely, that not every a priori cognition must be called transcendental, but only that by means of which we comprehend that and how certain representations (intuitions or concepts) are applied entirely a priori (A56/B80).

Kant here stresses that a synthetic a priori cognition — such as the principle that any event has a cause - is not itself a form of transcendental cognition. A pure concept such as causality emerges whenever human beings attempt to order their subsequent representations. Conversely, transcendental cognition consists in a deliberate reflection on a priori cognitions. ${ }^{17}$ In one way or another, this reflection has always been carried out in the discipline called first philosophy, general metaphysics, ontology, or fundamental science. What these various guises of transcendental philosophy have in common is the fact that they do not assume the existence of given objects. Insofar as they can be said to be concerned with objects at all, they do not deal with specific kinds of objects, but with that which all objects have in common, that is, with objects qua objects. ${ }^{18}$

By employing this formal conception of transcendental philosophy, Kant is able to determine the specific features — or failures — of the modes of transcendental philosophy preceding his own. Firstly, traditional forms of transcendental philosophy always ignored space and time qua a priori intuitions. In other words, they merely dealt with one kind of representation. ${ }^{19}$ Secondly, former guises of transcendental philosophy treated pure concepts without relying on a rigorous principle, and therefore attained mere aggregates rather than proper systems, as Kant repeatedly points out. ${ }^{20}$ Finally, transcendental philosophy always assumed that ontological concepts such as substance 
and causality could be applied indiscriminately to material things and to immaterial things such as the soul, the world as such, and God.

In my view, Kant primarily took issue with this last assumption. That is why his various definitions of transcendental philosophy include a reference to objects - taken in a formal sense - instead of things. By working with a formal notion of object, Kant could distinguish between forms of transcendental philosophy that uncritically identified objects with things and, on the other hand, a critical form of transcendental philosophy based on the insight that pure concepts can only be predicated of appearances, that is, of potential objects of experience. ${ }^{21}$ This crucial distinction between appearances and things as such allowed Kant to limit the realm of transcendental philosophy to a priori cognitions insofar as they pertain to objects of possible experience. He thus tightened the relation between transcendental philosophy and the natural sciences much more than Wolff had done. Yet Kant did not thereby abandon the domain of metaphysics. The selflimitation of metaphysics achieved in the Critique of Pure Reason is precisely one of the conditions of its transformation into a true science. ${ }^{22}$

\section{Transcendental Critique and Transcendental Philosophy}

So far I have focussed on Kant's conception of transcendental philosophy; I now turn to the way in which transcendental cognition is enacted in the first Critique. In my view, it is crucial to see that this work is made up of various complementary strands. Insofar as the Critique of Pure Reason treats of pure concepts and their corresponding a priori principles, it can be considered to contain a preliminary outline of the first-order transcendental philosophy which, as the first part of Kant's projected metaphysical system, carries out the task that used to be attributed to ontology. ${ }^{23}$ The Transcendental Aesthetic, the metaphysical deduction of the categories, and the chapter devoted to the principles of the pure understanding clearly belong to this first strand of the Critique of Pure Reason. Kant here presents the categories as determinations that must be predicated of any object if it is to become an object of experience, and of the judgements that carry out this predication - the principles of the pure understanding — as synthetic a priori judgments. ${ }^{24}$ Even Kant's confinement of the realm of synthetic a priori cognition to objects of possible experience does not really fall outside of the domain of first-order transcendental philosophy.

The same cannot be said of a second strand in the Critique of Pure Reason, which demonstrates why the concepts and principles to be treated within transcendental philosophy can only be applied to objects of possible experience. This strand consists in a second-order reflection on the limits within which synthetic a priori knowledge is possible at all. Kant sometimes refers to this strand as transcendental critique, an activity he distinguishes explicitly from transcendental philosophy: 


\section{Karin de Boer}

This investigation, which we can properly call not doctrine but only transcendental critique, since it does not aim at the amplification of the cognitions themselves, but only at their correction, and is to supply the touchstone of the worth or worthlessness of all cognitions a priori, is that with which we are now concerned. Such a critique is accordingly a preparation, if possible, for an organon and, if this cannot be accomplished, then at least for a canon, in accordance with which the complete system of the philosophy of pure reason ... can ... be exhibited (A12/B26; cf. A 761/B789).

What Kant calls transcendental critique is a form of transcendental cognition that consists in a deliberate reflection on first-order transcendental cognition, i.e. on the form of cognition that is concerned with pure concepts such as causality and a priori principles such as 'all events have a cause'. In other words, transcendental critique reflects on the very nature - and limits — of transcendental philosophy itself. Thus, in the same way as Wolff's ontology aimed to offer clear definitions of the concepts and principles presupposed by every science, Kant's transcendental critique aims to offer a clear definition of transcendental philosophy itself, that is, to define the limits within which the investigation into the a priori elements of knowledge can be carried out in a scientific way. ${ }^{25}$ This definition is achieved by conceiving of transcendental philosophy as a species of transcendental cognition and, on the other hand, as the genus of various historical instantiations of transcendental philosophy. Seen in this way, the diagram presented above can be complemented as follows: ${ }^{26}$

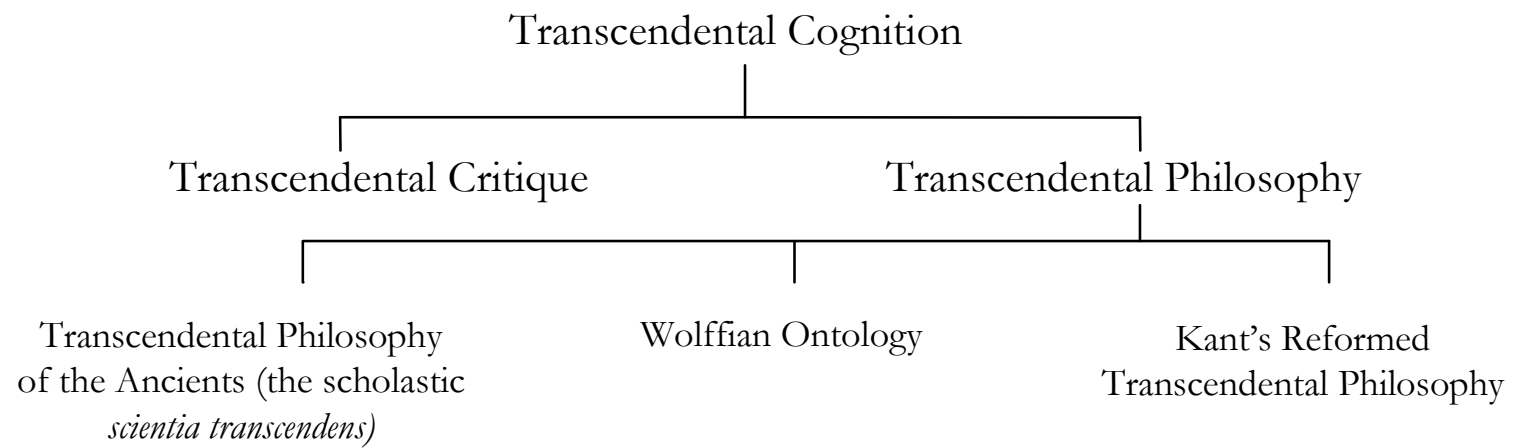

Thus, in order to define the limits within which transcendental philosophy is possible Kant starts out from a formal characterisation of transcendental cognition and, on that basis, analyses the characteristics of the various guises that this concept can assume. However, since the first Critique elaborates at the same time the basic elements of Kant's projected first-order transcendental philosophy, it is very hard to distinguish this selfreflective strand of the Transcendental Analytic from its other strands. 
Kant seems to have had in mind this second-order reflection on transcendental philosophy - that is, transcendental critique - when he, in various letters, referred to the philosophy carried out in the first Critique as a completely new discipline or as a metaphysics of metaphysics. ${ }^{27}$ These references cannot be used, therefore, to maintain that the discipline Kant calls transcendental philosophy is completely new in all respects. As I see it, Kant considered his pre-eminent contribution to philosophy to consist in the transcendental critique that purges metaphysics of its effort to achieve knowledge of the soul, the world as such, and God. He accepted the other premises — if not the actual elaboration - of the pre-critical transcendental philosophy exemplified by Wolff's ontology. The only essential feature he considered to be lacking from the latter was transcendental critique, as is clearly stated in the following passage from the preface to the second edition of the first Critique:

In someday carrying out the plan that criticism prescribes, i.e., in the future system of metaphysics, we will have to follow the strict method of the famous Wolff, the greatest of all dogmatic philosophers, who gave us the first example ... of the way in which the secure course of a science is to be taken, through the regular ascertainment of the principles, the clear determination of concepts, the attempt at strictness in the proofs ...; for these reasons he had the skills for moving a science such as metaphysics into this condition, if only it had occurred to bim to prepare the field for it by a critique of the organ, namely, of pure reason itself (CPR, Bxxxvi-xxxvii, my emphasis). ${ }^{28}$

It seems to me that Kant's distinction between transcendental critique and transcendental philosophy deserves much more attention than it has actually received. ${ }^{29}$ If this distinction is taken seriously, then it is only the propaedeutic task which Kant refers to as transcendental critique that might be called subjectivistic, for it defines the limits within which synthetic a priori knowledge is possible by examining the various faculties involved in the production of any kind of knowledge. Yet even in this context the term 'subjective' is misleading, because Kant from the outset conceived of his transcendental critique not as an end in itself, but as a means to free metaphysics from its unwarranted assumptions. This critique targets pure reason, that is, the mode of thought purportedly capable of achieving a priori knowledge of things independently of intuition. Accordingly, Kant's preliminary investigation into the human mind is intended to criticise the guises of transcendental philosophy he attributed to Scholasticism and Wolffianism rather than to lay bare the foundation of empirical knowledge. Already the first-order transcendental philosophy outlined in the Critique of Pure Reason consists in a reflection on the a priori elements of our cognitions. If this is the case, then transcendental idealism cannot consist in a set of claims about the existence of entities or their properties, including the claim 


\section{Karin de Boer}

that there are no mind-independent entities. As I see it, this term refers rather to the methodological necessity, within philosophy, of bracketing any concern with entities and focusing instead on the content of our representations. ${ }^{30}$

\section{Wolff's Use of the Terms, 'Ontology' and 'Transcendental'}

One of the obstacles to grasping the deep affinity between Wolff's ontology and Kant's first-order transcendental philosophy is undoubtedly the fact that Wolff chose to call the Latin version of his first philosophy 'ontology', while Kant referred to the same discipline as 'transcendental philosophy'. That is why most commentators who deal with this issue ignore Wolff and, instead, compare Kant's conception of transcendental philosophy with the Scholastic treatment of transcendentals and Kant's discussion of them in the second edition of the first Critique. ${ }^{31}$ If, by contrast, one takes into account Wolff's reason for referring to the first part of his metaphysics as 'ontology', then Kant's conception of transcendental philosophy may well turn out to be more akin to that of his immediate predecessors.

By the time Wolff elaborated his metaphysical system, the term 'transcendens' was no longer used primarily to refer to the determinations of being — including unity, truth, and perfection - that thirteenth-century scholars such as Aquinas and Duns Scotus considered to transcend the generality of the categories listed by Aristotle. ${ }^{32}$ Duns Scotus had already enlarged the domain of transcendentia with further predicates, coining the term scientia transcendens to refer to the discipline concerned with any of the determinations of being qua being. During the seventeenth century, this discipline also became known as scientia transcendentalis, a title that remained well-known up until Wolff's time. Thus, the terms 'transcendental science' and 'ontology' both came to refer to that part of metaphysics which was concerned with the determinations that can be predicated of all beings and, as such, provided the other disciplines with their basic principles.

Given this convergence between transcendental science and ontology, Wolff seems to have had the choice of either name. This view is supported by the fact that he refers to the Latin version of his general cosmology as cosmologia transcendentalis, thereby indicating that this discipline is concerned with the most general determinations that can be predicated of the world as such, in other words, with the most general concepts that we use to achieve knowledge of the world. For Wolff, transcendental cosmology differs from ontology only inasmuch as its domain is defined by the world as such rather than by all beings:

But there is also a general examination of the world, which clarifies the features that the existing world shares with any possible world. I will call the part of philosophy that develops these general and partly abstract concepts, general or transcendental cosmology. (DP S78) 
For that reason I tend to call it [cosmologia generalis] transcendental, because in it only such things are demonstrated of the world that accrue to it as to a composite and modifiable being, so that it indeed stands to physics in the same manner as ontology or first philosophy to universal philosophy. (CG, $\int 1$ note $)^{33}$

Thus, Wolff conceived of transcendental cosmology as the discipline that treats of the most general concepts that we use to achieve knowledge of the world, concepts that are necessarily presupposed in more concrete forms of knowledge about the world. Like ontology, transcendental cosmology does not assume the existence of actual beings. It merely treats of those conceptual determinations that would hold true of any possible world, thus providing the hinge between ontology on the one hand and physics on the other. ${ }^{34}$ Analogously, Wolff might have called the Latin version of his first philosophy 'transcendental science', as others had done before him. In his view, however, there was nothing wrong with the term 'ontology' - apart from its bad reputation among the Cartesians. Avoiding Latin terminology in his German works, he notes that he decided to use the term 'fundamental science' (Grundwissenschaft) as its German equivalent:

In German I call the ontologia fundamental science [Grundwissenschaft]. ... I need the term 'fundamental science' because in this part of philosophy one clarifies the first grounds of cognition. ... [A]part from this reason I also took into account the circumstance that one has currently thrown the baby out with the bathwater, at the cost of the sciences, and I have therefore chosen a name that indicates the utility of this science (AN \$17, 32-33). .35

The part of the German Metaphysics that corresponds to the Latin Ontology is simply called 'On the first grounds of our cognition and on all things as such'. Wolff here refers to the equivalent of his transcendental cosmology simply as 'On the world'. In his Latin works, however, Wolff uses the term 'transcendental' with regard to a doctrine that treats those concepts and principles of a specific discipline that are presupposed in the applied part of the same discipline and possibly in other disciplines. ${ }^{36}$ For this reason he might just as well have referred to the Latin version of his ontology as transcendental philosophy.

\section{Kant's Criticism of Wolff's Ontology and Tetens' Transcendental Philosophy}

I have argued that Kant disentangled the epistemological strand of Wolff's ontology which Wolff himself sometimes refers to as 'fundamental science' — from the assumption that the concepts it treated could be predicated of beings qua beings, and that the first Critique introduces a formal notion of transcendental philosophy to refer to this 


\section{Karin de Boer}

epistemological strand alone. This notion allowed Kant to conceive of Wolff's actual ontology as a pre-critical guise of transcendental philosophy, in other words, as a systematic reflection on a priori cognition which was as yet unaware of the limits imposed on pure reason. It emerges from Kant's Lectures on Metaphysics from 1782-1783 that he primarily took issue with Wolff's own understanding of the nature of the discipline he called ontology. In Kant's view, Wolff should have called his philosophy transcendental philosophy rather than ontology, because it in fact contains nothing but an analytic of the understanding and reason, that is, an analytic of the concepts and principles that these faculties produce, albeit an inadequate one. The term 'ontology' is misleading, Kant states in his lectures, because the reference to all beings amounts to a reference to nothing at all:

Thus the science of all basic concepts and basic propositions upon which all of our pure cognitions of reason rests is ontology. But this science will not be properly called ontology. For to have a thing in general as an object is as much as to have no object and to treat only of cognition, as in logic. The name, however, sounds as if it had a determinate object. But this science ... rather ... considers understanding and reason themselves, namely their basic concepts and basic propositions in their pure use (or of pure reason and pure understanding); the most fitting name would be transcendental philosophy (Metaphysik Mongrovius, AA 29: 786). ${ }^{37}$

This conception of transcendental philosophy is completely in line with the passages from the Critique of Pure Reason discussed above. Unlike the latter, however, Kant's lectures make it clear that his critique of Wolff's conception of ontology consists of two different elements. In Kant's view, first, Wolff should have realised that the 'proud name of ontology' actually means nothing other than transcendental philosophy, conceived as the analytic of thought, and should therefore be replaced by the latter. It is therefore not by coincidence that Kant in the first Critique attributes the predicate 'proud' to the name given to the discipline he himself prefers to call 'transcendental philosophy' rather than to the discipline itself. The second element in Kant's critique of Wolff is elaborated in the Critique of Pure Reason alone. Kant here considers the pride of ontology itself to be misguided because it assumed that the concepts and a priori principles it treated could be used in general cosmology, rational psychology and natural theology as well as in sciences concerned with the objects of possible experience. Unlike the term 'ontology', the term 'transcendental philosophy' leaves open the question of the kinds of things to which pure concepts can be applied.

As Krouglov points out, Kant's decision to use the term 'transcendental philosophy' in German is likely to have been influenced by Tetens, who had published a treatise titled Über die allgemeine speculativische Philosophie in 1775. ${ }^{38}$ In this work, Tetens uses the term 'general transcendent philosophy' to denote that part of metaphysics which is 
devoted to the highest and most general principles of human cognition. Tetens describes these principles as follows:

[These principles] consist in certain general judgments about the relations between things and their properties. The first, most general concepts are our representations of things or objects as such, that is, they are ideal objects in us. (Tetens 1775: 36)

Transcendent philosophy ... is nothing but a general theory that in itself is no more concerned with actual things than the analysis of the mathematicians. It has the same nature as the latter, and it might well be called a higher analysis of things, if it did not possess a sufficient number of names and titles already. (Tetens 1775: 24)

Thus, Tetens' conception of transcendental philosophy is quite close to Kant's in at least some respects. According to Kant, however, even Tetens did not carry out the specific kind of reform at stake in the Critique of Pure Reason, because he, no less than Wolff, assumed that the pure concepts treated in transcendental philosophy could be applied to material as well as to immaterial things. That is why Kant in his lectures from 1782-1783 takes issue with Tetens' post-Wolffian transcendental philosophy as much as with Wolffian ontology:

No one has had a true transcendental philosophy. The word has been used and understood as ontology, but (as is easy to make out) this is not how we are taking it. In ontology one speaks of things in general, and thus actually of no thing - one is occupied with the nature of the understanding that thinks of things - here we have the concepts through which we think things, namely, the pure concepts of reason - hence it is the science of the principles of pure understanding and of reason (Metaphysica Mrongovius, AA 29: 752, my emphasis). ${ }^{39}$

What is lacking in both Wolffian ontology and the versions of transcendental philosophy known to Kant is, in short, a preliminary reflection on the limit of the domain within which pure concepts can be applied, a form of reflection which his lectures also refer to as critique:

The critique of pure reason belongs necessarily to transcendental philosophy. But since one used to treat ontology without a critique what was ontology then? An ontology that was not a transcendental philosophy (Metaphysica Mrongovius, AA 29: 784-5). 


\section{Karin de Boer}

This passage is somewhat confusing because Kant here does not use the term 'transcendental philosophy' in the formal sense of any investigation into the concepts and principles produced by pure understanding and pure reason. In this context it seems to refer merely to the projected first-order transcendental philosophy that has already emancipated itself from its preoccupation with beings qua beings.

At any rate, Kant did not adopt the term 'transcendental philosophy' because of the Scholastic discussion of transcendentalia such as unity, truth, and perfection. After Wolff, Lambert and Tetens had begun to use the term in German for their own versions of the discipline that Wolff had called ontology. Even though Kant regarded these versions as inadequate, he probably coined his version of the term 'transcendental philosophy' on the basis of theirs because it had the advantage of completely leaving open what kinds of objects were at stake in this discipline.

The Reflections on Metaphysics make it clear that, before publishing the Critique of Pure Reason, Kant wavered between various ways of fixing the term 'transcendental philosophy'. Even in later texts he sometimes identifies transcendental philosophy with the propaedeutic task carried out in this work rather than with the first part of any metaphysical system. I take the view, however, that the various references to transcendental philosophy in the Critique itself are consistent. This consistency can only emerge, as I have tried to show, by assuming that the term 'transcendental philosophy' primarily denotes the formal core of the discipline formerly called first philosophy, general metaphysics, fundamental science, or ontology. While, on this account, Kant's second-order reflection on the conditions of possibility of this discipline might be called transcendental philosophy as well, as Kant sometimes does, I hold that his use of the term 'transcendental critique' is more appropriate for this task.

\section{Hegel's Transformation of Kant's Transcendental Philosophy}

The account of Kant's conception of transcendental philosophy presented so far sheds a different light on the relation between the Critique of Pure Reason and Hegel's Science of Logic as well as on Hegel's prevailing assessment of that relation. In agreement with his later Lectures on the History of Philosophy, Hegel notes in the Logic that Kant's philosophical interest was 'exclusively' directed at the subjective origin of a priori knowledge (L I, 59/62). Opposing Kant's alleged subjectivism, he presents the Logic as a work that establishes a system of the determinations of thought such as they are in and for themselves:

Because the interest of the Kantian philosophy was directed to the socalled transcendental aspect of the categories, the treatment of the categories themselves yielded a blank result; what they are in themselves 
without the abstract relation to the ego common to all, ... this has not been made an object of consideration (60/63; cf. 45/51).

On closer inspection, however, Hegel more or less implicitly admits his indebtedness to Kant. Thus, he admits that his logic 'corresponds in part' to Kant's transcendental logic, namely insofar as Kant himself had already treated of 'the concepts which refer a priori to objects' (59/62). No less implicitly, he also endorses Kant's criticism of metaphysics:

Former metaphysics ... incurred the just reproach of having employed these forms uncritically without a preliminary investigation as to whether and how they were capable of being determinations of the thing-in-itself, to use the Kantian expression, or rather of the reasonable (61-62/64). ${ }^{40}$

Whereas Hegel here seems to agree with Kant that such a preliminary investigation is required in order to turn metaphysics into a science, he seems to disagree with the result allegedly achieved by Kant. Accordingly, Hegel presents his objective logic as the 'true critique' of the determinations of pure thought, a critique, that is, which examines the 'particular content' of these determinations one by one (62/64). Since the objective logic deals with the same contents as former metaphysics, albeit in a critical manner, Hegel can maintain that this part of the Logic replaces metaphysics, in particular Wolffian ontology:

The objective logic, then, rather takes the place of former metaphysics, which was intended to be the scientific construction of the world in terms of thought alone. If we have regard to the final elaboration of this science, then it is first and immediately ontology whose place is taken by objective logic - that part of this metaphysics which was supposed to investigate the nature of ens in general; ens comprising both being and essence. ... But further, objective logic also comprises the rest of metaphysics insofar as this attempted to comprehend ... the soul, the world, and God (61/63-64, my emphasis). ${ }^{41}$

This passage clearly brings out Hegel's significant indebtedness to Kant. For, as we have seen, Kant himself no less considered his transcendental philosophy as a replacement of Wolffian ontology. Like Wolffian ontology and Kant's projected transcendental philosophy, Hegel's Logic investigates the totality of pure concepts constitutive of any knowledge of objects (cf. L I, 30/39-40). Hegel considered his Logic to replace Wolffian ontology by enacting a critique of the pure concepts that emerged during the history of thought, that is, by letting each of them become aware of its proper limit. ${ }^{42}$ If we disregard the difference between the methods employed or advocated by Wolff, Kant, and Hegel, then the critical investigation of pure concepts carried out in the Logic can be 


\section{Karin de Boer}

said to constitute a specific form of transcendental philosophy in the Kantian sense of the term. If this is the case, then we can no longer take our bearings from Hegel's criticism of Kant's exoteric doctrine in order to grasp the nature of the reforms of Wolffian ontology at stake in the Critique of Pure Reason and the Science of Logic.43

\section{Karin de Boer \\ University of Leuven}

Email

karindeboer@cs.com

\section{Notes}

Abbreviations:

VG: Wolff, C., Vernünftige Gedancken von Gott, der Welt und der Seele des Menschen, auch allen Dingen überbaupt [1720].

DP: Wolff, C., Discursus Praeliminaris de Philosophia in Genere / Einleitende Abhandlung über Philosophie im allgemeinen [1728].

PPO: Wolff, C., Philosophia prima sive ontologia / Erste Philosophie oder Ontologie [1729].

CG: Wolff, C., Cosmologia Generalis [1731].

AN: Wolff, C., Ausfübrliche Nachricht von seinen eigenen Schriften, die er in Deutscher Sprache herausgegeben [1733].

PM: Kant, I., 'The Employment in Natural Philosophy of Metaphysics combined with Geometry, of which Sample I Contains the Physical Monadology' [1756].

CPR: Kant, I., Kritike der reinen Vernunft / Critique of Pure Reason [1781/1789].

Prol: Kant, I., Prolegomena zu einer jeden künftigen Metaphysik die als Wissenschaft wird auftreten können / Prolegomena to Any Future Metaphysics That Will Be Able to Come Forward as Science [1783].

Refl: Kant, I., Reflektionen zur Metaphysik.

Enc I: Hegel, G. W. F., Enzyklopädie der philosophischen Wissenschaften im Grundrisse I / Hegel's Logic [1817-1830].

L I, II: Hegel, G. W. F., Wissenschaft der Logik / Science of Logic [1812-16, 1831].

LHP III: Hegel, G. W. F., Vorlesungen über die Geschichte der Philosophie / Lectures on the History of Philosophy III [1805-1831].

${ }_{1}$ Thus, the editors of the Historisches Wörterbuch der Philosophie, drawing on the contribution by Hinske, summarise the change undergone by the concept of the transcendental as follows: 'From the time of its origination until immediately prior to Kant, the concept of transcendentia, which during the late Medieval period was turned into the concept of "transcendentalia" without loss of meaning, referred ontologically to the most general determinations of beings, that is, it presupposed the possibility of an immediate cognition of objects. In Kantian and post-Kantian philosophy, by contrast, the term is used as a predicate of the cognition that is concerned with the a priori conditions of possibility of experience' (Ritter and Gründer 1998: 1358-1359). Whereas this description is not exactly wrong, the editors fail to point out that the conditions of possibility of experience at stake in the Critique of Pure Reason include precisely pure concepts such as substance and causality, concepts of which Kant conceived as the most general determinations of 
objects qua objects of possible experience. Considered in this way, the gap is reduced to the difference between the domains of which these determinations are predicated: things as such or objects of possible experience.

${ }^{2}$ Cf. CPR, Axii.

${ }^{3}$ CPR, Bxv, Bxviii-xix; cf. Prol 371). Commentators who have recently defended similar perspectives on the CPR include Fulda (1988) and (1999), Grondin (1989), Baum (1986) and (1993), Benoist (1996), and Schnepf (2007). Their readings differ substantially not only from the 'analytical' interpretations of Kant put forward by Strawson (1966) and Guyer (1987), but also from Allison's more nuanced, epistemological reading in Allison (2004: see note 31). 'Unlike Locke's,' Guyer notes, Wolff's philosophy 'cannot even be compared with the constructive elements of Kant's own' (Guyer 1987: 429, note 1). Whether this is indeed the case, however, depends on whether these elements are themselves framed in terms of a Lockean account of the way in which we achieve empirical knowledge or rather — as I propose — in terms of our capacity to produce and employ synthetic a priori principles.

${ }^{4}$ See Pippin (1989) and Stern (2009) for examples of non-metaphysical and metaphysical readings of Hegel's Science of Logic. In the Introduction to his book Stern basically argues that Hegel has more in common with pre-Kantian metaphysics than with what he - like many other commentators - refers to as Kant's 'metaphysics of experience' (Stern 2009: 8). This claim is at least partly based on the view that pre-Kantian ontology consists in a straightforward inquiry into being qua being or, as Stern also puts it, into 'the fundamental nature of being' (Ibid.: 19). If, however, Wolff's conception of ontology does not really fit this description, as I will argue in this article, then there might be less ground for opposing Hegel's attempt to 'restore the proud name of ontology in some form' (Ibid.: 21) to Kant's purportedly modest 'inquiry into the structure of our thought and experience' (Ibid.: 20). Interestingly, Pinkard conceives of Hegel's Science of Logic as a 'purely conceptualist' ontology and of Hegel as 'a kind of transcendental philosopher' (1979: 428, 435). This description remains a bit vague, however, because Pinkard does not dwell on Kant's own conception of transcendental philosophy and its relation to Wolffian ontology.

${ }^{5}$ In De Boer (2011) I defend a similar position, but here by focusing on the way Kant and Hegel conceived of a system of pure reason. Fulda likewise argues that Hegel's Science of Logic should be read in light of Kant's transformation of Wolff's conception of ontology (1999: 476). However, since Fulda accepts Hegel's 'subjectivistic' interpretation of the term 'transcendental philosophy' (Ibid.: 478) he underestimates, in my view, the continuity between Wolff, Kant, and Hegel. The same can be said of Bouton (1994) and Cramer (2001), who, focusing on the relation between Wolff's ontology and Hegel's Science of Logic, hardly examine Kant's conception of transcendental philosophy. Despite the fact that Cramer, moreover, does not question Hegel's critique of Kant, I largely endorse his perceptive interpretation of the way in which Kant and Hegel attempted to transform the conception of ontology developed by Wolff. See Mabille (2004: esp. Ch. 4 and Ch. 5), for a detailed reading of Kant's and Hegel's conceptions of metaphysics that does not take for granted Hegel's critique of Kant. Ameriks (1985) likewise takes issue with Hegel's critique of Kant's theoretical philosophy, but he focuses on Kant's 


\section{Karin de Boer}

transcendental deduction and his idealism rather than the issue of transcendental philosophy.

${ }^{6}$ Hinske (1968: 112) refers to a commentator (Buhle) who already in 1798 proclaimed Kant to be the discoverer of transcendental philosophy. Cf. Hinske (1970: 23-24) and Krouglov (2004: 41).

${ }^{7}$ Cf. LHP III, 333. The Science of Logic, by contrast, offers an adequate description of the term 'transcendental logic' (L I, 59). I come back to this text in Section VIII.

${ }_{8}$ 'The exoteric doctrine of the Kantian philosophy — that the understanding ought not to go beyond experience, else the cognitive faculty will become a theoretical reason which by itself generates nothing but chimaeras — has provided scientific thought with a justification of their renunciation of speculative thought' (L I, 13/25).

9 These developments are sketched very clearly in Vollrath (1962). According to Vollrath, from the 1650s onward various philosophers attempted to resolve the ambiguities in Aristotle's conception of metaphysics by distinguishing between first philosophy (qua universal science) and metaphysics (qua knowledge of God, angels, and human souls). This distinction found fertile soil in the Protestant school of philosophy in seventeenthcentury Germany. Goclenius is apparently the first to have referred to the discipline concerned with (the determinations of) being qua being as 'ontology'. Micraelius called the same discipline general metaphysics and referred to its counterpart as special metaphysics (concerned with God, angels, and the human soul). In his Meditations on First Philosophy (1641) Descartes considers not only God and the soul, but also the realm of material beings as subjects of first philosophy. This threefold division of first philosophy was taken up by Wolff, who divided metaphysics into ontology on the one hand, and general cosmology, rational psychology, and natural theology on the other, a division that became standard during the eighteenth century. This fourfold division is clearly expressed in the title of Wolffs German Metaphysics (Rational Thoughts on God, the World and the Soul of Man, and also on All Things as Such), even though the work actually includes a chapter on empirical psychology. Wolff considered the material world, the soul, and God as the three 'things' that can be known and, as such, are treated in the three main parts of philosophy (DP \$55; cf. 56, 99, AN \$4). Contrary to DP $\$ 73$ and $\$ 99$, Wolff at $\$ 55$ apparently disregards ontology. Baumgarten's Metaphysica is also divided according to these four main disciplines. On this topic, see also Mora (1963), Honnefelder (1990), and Sala (1988). As I see it, Kant assumed that his readers were familiar with the traditional guise of the division between general and special metaphysics, as is brought out, for instance, by his reference to these disciplines as the 'first part' and the 'second part' of metaphysics (CPR, Bxviii-xix). The distinction between general and special metaphysics clearly corresponds to Kant's distinction between transcendental analytic and dialectic (see Mabille 2004: 154).

${ }^{10}$ Cf.: 'Since, therefore, ontological definitions and propositions can be applied to any being whatsoever ... ontology proves to be useful everywhere. Consequently, when we elaborate proofs of principles until they can be grasped a priori, we ultimately always reach the principles of first philosophy, without which the other disciplines cannot achieve demonstrative knowledge' (C. Wolff, PPO \$9). Cf. PPO \1, where Wolff likewise notes that ontology, qua science of being in general, is concerned with the first principles of all reasoning. The second chapter of Wolff's German Metaphysics is entitled, 'On the 
First Grounds of Our Cognition and of All Things as Such', which suggests that Wolff considered these two approaches to the task of ontology to amount to the same thing. In his intellectual autobiography, Ausfübrliche Nachricht (1733), Wolff writes that he decided not to dispense with ontology because the concepts that used to be treated within this discipline are needed in cosmology and theology (AN \$\$ $568-69$; cf. DP \$S94, 97-98). Honnefelder points out that Wolff regarded ontology as a discipline concerned with pure concepts - to be discovered by means of analysis - that make it possible to achieve knowledge of beings. Accordingly, "the "transcensus" of ontology ... can no longer be understood primarily as the act of moving beyond the categories, but should rather be understood as the act of moving from that which is grounded towards its conditioning first grounds' (1990: 321; cf. 322). Bouton likewise argues that Wolff, without being fully aware of it, achieved the 'noetisation' of ontology initiated by Suarez and Descartes (1996: 250, cf. 253, 258). See Benoist (1996: 147-149) for a similar view. By contrast, Demange (2009) maintains that the development of metaphysics during the seventeenth and eighteenth centuries cannot be understood in terms of a straightforward shift from metaphysics (being) to the theory of representation (object).

${ }^{11}$ C. Wolff, DP \$29, 31; cf. Schnepf (2007: 89).

12 A. G. Baumgarten, Metaphysica $\int \$ 4-5$.

${ }^{13}$ I will come back to this development in section VI.

${ }_{14}$ Cf. Bärtlein (1953/54: 357). Kant's Reflexions on Metaphysics from 1769-70 contain passages in which the term 'transcendental' is used in a similar way: 'That ontology is nothing but a transcendental Logic, whereas applied metaphysics [is] merely negative, and nothing remains but morality, the data of which are produced by the human will' (Refl. 4152).

${ }^{15}$ In the second edition, 'our a priori concepts of objects as such' is replaced by 'our mode of cognition [Erkenntnisart] of objects insofar as this is to be possible a priori' (B25). Clearly, the term 'a priori mode of cognition' covers more than 'a priori concepts' alone. The Critique of Pure Reason uses the term 'mode of cognition' with regard to intuition and thought qua activities carried out by the human mind (B318) as well as with regard to the products of these activities such as pure concepts (B306), judgements (A6), and experience (A157). Thus, while the phrase in the first edition is closer to the traditional conception of transcendental philosophy, the phrase in the second edition encompasses more adequately both transcendental philosophy as the first part of a metaphysical system and the mode of transcendental cognition which Kant calls transcendental critique, that is, the investigation of pure concepts in light of the various faculties involved in their production and application (cf. A12/B26). See Pinder (1986) for a detailed discussion of these passages, especially of the peculiar expression 'nicht so wobl ... sondern'. Philological difficulties apart, it seems to me that Kant, by putting it this way, may well have meant to say that transcendental cognition differs from both empirical cognition and special metaphysics because it is not concerned with particular objects, and from general logic because it is nevertheless concerned with objects as such, namely, with the pure intuitions, pure concepts, and a priori principles that allow us to turn a manifold into an object of knowledge in the first place. See also Schnepf (2007: 7583, 103-106). 
${ }^{16}$ In a similar, but more schematic passage in Kant's Reflections on Metaphysics (dated 17761778) the terms metaphysica generalis and metaphysica specialis are added as equivalents to (1) transcendental philosophy as the investigation into reason and the concepts which reason itself produces and (2) rational physiology as the investigation into objects that differ from reason itself (Refl. 4851).

${ }^{17}$ Cf. the following note from the Reflections on Metaphysics (1776-1778): 'A priori cognition is being opposed to empirical cognition; the philosophy that deals with this cognition is transcendental philosophy [Philosophie über dieselbe ist transscendentalphilosophie] (Refl. 4890). Here, as well as in the Critique of Pure Reason, Kant's definitions deliberately leave open the question of whether transcendental philosophy carries out the reflection on a priori cognition dogmatically or critically. The distinction between transcendental critique and transcendental philosophy (conceived as two modes of transcendental cognition) does not yet seem to be in place here.

${ }_{18}$ See Pinder (1986: esp. 14-20).

19 That is why Definition 3 (A56/B80) uses the general term 'representations' in the main sentence.

${ }_{20}$ CPR, A64/B89, A831-32/B859-60. See Zöller (2001) for a clear account of the difference between Kant's conception of a system and that of Wolff and Baumgarten.

${ }_{21}$ 'The principles of pure understanding ... contain nothing but the pure schema, as it were, for possible experience' (A236-7/B296). 'The transcendental use of a concept in any sort of principle consists in its being related to things as such and in themselves; its empirical use, however, in its being related merely to appearances, i.e., objects of a possible experience. But that only the latter can ever take place is evident from the following.' (A238-9/B297-8; cf. Bxxvii). I take it that Kant uses the expression, 'transcendental use' to refer to the way in which former general metaphysics applied pure concepts to things as such without discriminating between material and immaterial things or, in his terms, between things that can be treated as either phenomena or noumena (such as billiard balls) and things that can only be treated as noumena (such as the soul). Cf. B306; on this topic, see De Boer 2010a). See Cramer (2001: 202) and Benoist (1996: esp. 142-143, 152$153,156)$ for interpretations that also emphasise the shift from 'things' to 'objects' accomplished in the CPR. Unlike Fulda (1988: 51), however, Benoist downplays Kant's determination of objects as such in terms of objects of experience (cf. 153). Sala likewise seems to ignore this restriction. Accordingly, he claims that, for Kant, transcendental analytic and ontology basically refer to the same discipline (1988: 22, 37, 44) and he is not very specific about the nature of Kant's reform of the latter (cf. 35).

${ }^{22}$ As is well-known, Kant considered the self-limitation of pure theoretical reason ance to allow practical philosophy to emancipate itself from the dogmatic treatment of human freedom, the soul, and God in what was formerly called special metaphysics (cf. Bxxi, Bxxxii-xxxiv). This topic falls outside the scope of the present article.

${ }_{23}$ 'Transcendental philosophy is here [in the Critique of Pure Reason] the idea of a science, for which the Critique of Pure Reason is to outline the entire plan architectonically, i.e., from principles, with a full guarantee for the completeness and certainty of all the components that comprise this edifice' (A13/B27). Contrary to the translators, I take Kant here to refer to the book titled Critique of Pure Reason rather than to the activity denoted as critique, for the latter is precisely not involved in presenting the outline of Kant's 
projected first-order transcendental philosophy (the complete elaboration of which he never achieved). In his discussion of Kant's lectures on Baumgarten's Metaphysics, Ameriks deplores 'the fact that Kant's own written work hardly presents a thorough treatment of "immanent" ontology' (2003: 120). I take the view, by contrast, that the Transcendental Analytic itself — insofar as it treats of pure concepts and a priori principles - precisely constitutes a preliminary elaboration of the task formerly assigned to ontology (albeit not yet in the form of a complete system).

${ }^{24}$ Cf. CPR, A136/B175, A154/B193. In the Critique of the Power of Judgment, Kant refers to the pure concepts of the understanding as 'ontological predicates' (AA 5: 181). The Critique of Pure Reason conceives of the pure concepts as predicates that the understanding attributes to objects qua objects or objects as such (cf. A219/B266, A233/B286, A290/B346; see Pinder 1986: 22). The view that Kant conceived of one of the strands of the Critique of Pure Reason as a preliminary elaboration of his projected first-order transcendental philosophy is supported by the following passage: 'To the Critique of Pure Reason belongs therefore everything that constitutes transcendental philosophy, and it is the complete idea of transcendental philosophy, but it is not yet this science itself, since it goes only so far in the analysis as is required for the complete estimation of synthetic a priori cognition' (A14/B28). When Kant later on refers to this analysis as the 'proper business' of transcendental philosophy (A66/B90-91) he seems to use the term 'transcendental philosophy' in a sense that encompasses both transcendental critique and transcendental philosophy as the first part of metaphysics.

${ }_{25}$ Cf. the following passage from Kant's Lectures on Metaphysics (1784-1785): 'The definition of a science that is supposed to contain the first principles of all human cognition is not determinate enough, for if I say that it is a science of the first principles of all human cognition then I have not obtained a determinate concept, and I cannot know how far this science will go, or whether it should rather begin by coming to a halt' (Metaphysik Volckmann, AA 28: 357; cf. Metaphysik L, AA 28: 223). Hinske (1968: 112) maintains that the concept of the transcendental such as it occurs in the Critique of Pure Reason cannot be grasped by means of a single definition (cf. Hinske 1970: 16). However, at least the term 'transcendental philosophy' as Kant uses it in the Critique of Pure Reason does not challenge such a definition. Interpreting the other occurrences of the term 'transcendental' in light of Kant's formal conception of transcendental philosophy falls outside of the scope of this article.

${ }_{26}$ This diagram is limited to the theoretical or 'speculative' part of metaphysics (as opposed to the part of metaphysics devoted to morality (cf. CPR, A841/B869). According to Kant, transcendental philosophy constitutes the first part of the theoretical branch of metaphysics. The diagram also abstracts from the other parts of theoretical metaphysics, which together can be considered to replace the old 'special metaphysics' (cf. A845/B871).

${ }^{27}$ Cf. the letter to Herz dated $11^{\text {th }}$ May 1781, in which Kant famously refers to the Critique of Pure Reason as a work that 'contains the metaphysics of metaphysics' (AA 10, 269). The term 'contains' is relevant here, because it does not exclude the possibility that the Critique of Pure Reason contains other elements as well, such as a sketch of first-order metaphysics, the very possibility of which is reflected upon by second-order metaphysics. 
Baum (1993: 13) also takes this passage to concern Kant's idea of a transcendental critique. When Kant in his letter to Garve from 7 th August 1783 refers to the Critique of Pure Reason as 'not metaphysics at all, ... but a completely new and thus far never attempted science', he seems to refer exclusively to this second-order metaphysics.

${ }_{28}$ The fact that Kant elsewhere in the Critique criticises Wolff's view that philosophy should employ the same method as mathematics (A726-27/B754-55) does not imply that he rejected Wolff's method - or his conception of philosophy — in all respects. See Zöller (2001: 56).

29 Arguing that one searches in vain for a unifying meaning of the term 'transcendental' in Kant's works, Hinske (1998: 1382) distinguishes between the following three meanings of transcendental philosophy in the Critique of Pure Reason: (1) any form of a priori cognition, (2) Kant's critical reflection on the latter, and (3) the investigation into the possibility of a priori cognition. As I see it, however, there are no passages in the CPR itself that support (1). Although I agree with Hinske's description of (2), he does not mention that Kant refers to this strand as transcendental critique rather than transcendental philosophy. I do not see, moreover, why Hinske distinguishes between (2) and (3). What seems to be missing in Hinske's account, finally, is the guise of transcendental philosophy which Kant conceived of as the first part of his metaphysical system, in other words, the guise that shares common ground with Wolff's ontology. Tonelli (1994: 76-77) notes with reference to Kant's distinction between transcendental critique and transcendental philosophy that the former 'is meant to encompass the principles of the synthesis', a description that he takes to be at odds with Kant's assertion that the critique has a merely negative aim. This confusion emerges, it seems to me, because Tonelli does not take into account the fact that transcendental critique and (first-order) transcendental philosophy treat the same synthetic a priori principles from a different perspective and with a different aim.

${ }^{30}$ Contrary to Guyer, amongst others, Allison also conceives of Kant's transcendental idealism as a methodology rather than as a metaphysical doctrine (2004: xv). In his view, Kant uses this methodology - and the ensuing distinction between appearances and things in themselves - to analyse the nature of human cognition (4) and to lay bare the epistemic conditions that make it possible to represent something as an object (Ibid.: 11). Whereas I completely endorse Allison's critique of Guyer, I do not agree with his interpretation of Kant's reflection on the conditions of human cognition in epistemological terms. By assuming that Kant was primarily concerned with the conditions of empirical cognition, Allison no less than Guyer underestimates the extent to which Kant's reflection on the conditions of human cognition was aimed primarily at the metaphysics of his predecessors.

31 I consider Kant's own remarks on the treatment of transcendentals in the 'transcendental philosophy of the ancients' in the second edition of the Critique of Pure Reason (B113-116) to be not very helpful in clarifying the conception of transcendental philosophy at stake in this work. Here I agree with Demange (2009), who points to the opposition between the scholastic theory of the transcendentals and Kant's conception of transcendental philosophy. However, the gap between Kant and his predecessors turns out to be smaller than Demange claims if Wolff's 'epistemological' conception of ontology is taken into account. Commentators who interpret Kant's conception of transcendental philosophy in light of the scholastic tradition without referring to Wolff 
include Knittermeyer (1953/54) and Doyle (1997). Bärthlein (1976) discusses Wolffs ontology primarily with regard to its discussion of the scholastic doctrine of the transcendentals; Angelelli (1972) adopts a similar approach with regard to Baumgarten's Metaphysics. Focusing on Wolff's use of the term 'transcendental cosmology', Hinske (1968) does not dwell on Wolff's conception of ontology either. The same applies to Hinske (1970; cf. 54, 79).

32 Drawing on earlier elaborations, Aquinas distinguished six transcendentals (ens, res, aliquid, unum, verum, bonum), that is, determinations that transcend the difference between infinite and finite beings and accordingly must be predicated of all beings. Duns Scotus enlarged the number of transcendentia by including conceptual determinations that come in pairs, such as necessity and possibility, and finite and infinite, because one of them can always be predicated of a being. He was the first to refer to the science that is concerned with the transcendentals as scientia transcendens, identifying this science with metaphysics. Thanks to Suarez, among others, this conception of metaphysics became influential during the seventeenth and the early eighteenth century. The same discipline also became known as theoria, scientia, or philosophia transcendentalis (rather than transcendens), terms with which Wolff was familiar. As was noted above, the term 'ontology' was similarly introduced in the seventeenth century to denote the part of metaphysics concerned with the determinations that can be predicated of all beings. Detailed accounts of these developments can be found in Honnefelder (1990) and Courtine (1990). See also Hinske (1968), Bärthlein (1976), Honnefelder (1995), Ritter and Gründer (1998: 1358-1379), Krouglov (2004: 48-49), Demange (2009). See Hinske (1970) for a discussion of Kant's use of the term 'transcendental' in his pre-critical, Reflections on Metaphysics.

33 Cf. Vollrath (1962: 261-262), Hinske (1968: 98-103), Bärthlein (1976: 357-358), Honnefelder (1995: 397). In a passage from the Reflections on Metaphysics (dated 1769) Kant draws a similar analogy between metaphysics or pure philosophy and pure mathematics, both of which are distinguished from the applied forms of the same disciplines.

${ }^{34}$ Cf. C. Wolff, DP $\$ 94,97$.

${ }_{35}$ Cf. PPO \$1. Wolff apparently preferred the term 'fundamental science' because of the bad name which the term 'ontology' had in Cartesian circles. He suggests that the best way to save ontology (the child) from its scholastic elaboration (the bathwater) was to rebaptise it with an untainted name.

${ }_{36}$ According to Hinske (1968), Wolff was the first to use the term 'transcendental' with regard to a discipline he considered to be a part of special metaphysics (cosmology) rather than with regard to general metaphysics. In his view, Wolff's use of the term 'transcendental' still testifies to the original meaning of transcendere, namely, insofar as his cosmology can be said to treat of concepts and principles that move beyond empirical knowledge (102). As I see it, by contrast, Wolff merely uses the term to refer to a doctrine that treats the concepts and principles of a specific discipline that are presupposed in the applied part of the same discipline and possibly in other disciplines (see Honnefelder 1995: 397, 399). This clarifies why Kant in the Critique of Pure Reason, in line with Wolff's use of the term, attributes the term 'transcendental' not only to philosophy as such (to denote the discipline formerly called ontology), but, analogously, also to parts of philosophy formerly considered to belong to special metaphysics (cf. CPR, A441/B469, 
A580/B608), to the ideas of reason (A321/B378), and, of course, to the parts of the Critique of Pure Reason itself. In the Transcendental Dialectic, Kant refers implicitly to Wolff's transcendental cosmology (A334/B391-2). As in the case of Wolff, I do not consider it helpful to interpret Kant's use of the term 'transcendental' in the Critique of Pure Reason in light of the meaning of transcendere.

${ }_{37}$ Cf. I. Kant, Metaphysike Mongrovius, AA 29: 784-785; cf. also Metaphysike Vockmann, AA 28: 390-391 and the following passage (dating from around 1790): 'But the question arises: how are the a priori cognitions possible? The science that answers this question is called critique of pure reason. Transcendental philosophy is the system of all our pure a priori cognitions; customarily it is called ontology. Ontology thus deals with things in general, it abstracts from everything particular. It embraces all pure concepts of the understanding and all principles of the understanding or of reason' (Metaphysik L2, AA 28: 541). Whereas Kant clearly distinguishes between critique and transcendental philosophy, here and elsewhere he refrains from presenting his own view concerning the difference between things in general (the domain of former ontology) and possible objects of experience (the domain of his reformed transcendental philosophy).

${ }_{38}$ See Krouglov for a highly illuminating account of these developments. According to Krouglov, Lambert was the first to render the Latin term transcendentalis in German as 'transcendent', and this without as yet distinguishing between transcendent and transcendental (2004: 46-47). Only Kant established that distinction in German (ibid.: 47). The passages from 'Tetens' Über die allgemeine speculativische Philosophie to which I refer are cited and commented upon in Krouglov (2004). See also Benoist (1996: 153).

${ }^{39}$ In a note dated 1776-1778, Kant writes that his transcendental philosophy has nothing to do with Tetens' Lockean investigation into the production of concepts, because the latter - as with Lambert's work - did not question the objective validity of pure concepts (Refl. 4900; cf. 4901).

${ }^{40}$ Cf. L I, 45/51. By contrast, Fulda (1988: 59-61) claims that Hegel in the Logic does not endorse Kant's critique of ontology.

${ }^{41}$ Clearly, Hegel no less than Kant assumed that his readers were familiar with the distinction between general and special metaphysics. Hegel's description of former metaphysics as a construction of the world in terms of thought alone is very similar to Kant's description at A270/B326. The order in which Hegel enumerates the ideas of reason is likewise Kantian. I take it that Hegel here and elsewhere primarily uses the term 'former metaphysics' to refer to Wolff's and Baumgarten's systems. In the Encyclopaedia he refers to former metaphysics as the philosophy that prevailed in Germany until Kant (Enc I, \27).

${ }^{42}$ Cf. De Boer (2010b: Chs. 2 and 3).

43 I would like to thank Manfred Baum, Bob Stern, Job Zinkstok, Colin McQuillan, and the editors of this special issue for their helpful comments and suggestions on an earlier version of this paper.

\section{Bibliography}

Allison, H. (2004), Kant's Transcendental Idealism: An Interpretation and Defense. New Haven and London: Yale University Press, originally published in 1983. 


\section{Transformations of Transcendental Philosophy: Wolff, Kant, and Hegel}

Angelelli, I. (1972), 'On the Origins of Kant's “Transcendental”, Kant-Studien 63(1): 117 122.

Ameriks, K. (2003), 'The Critique of Metaphysics: Kant and Traditional Ontology', in Interpreting Kant's Critiques. Oxford: Clarendon Press: 110-156, originally published in 1992.

Ameriks, K. (1985), 'Hegel's Critique of Kant's Theoretical Philosophy', Philosophy and Phenomenological Research XLVI/1, 1-35.

Bärthlein, K. (1976), 'Von der "Transzendentalphilosophie” der Alten zu der Kants', Archiv für Geschichte der Philosophie 58: 353-392.

Baum, M. (1986), Deduktion und Beweis in Kants Transzendentalphilosophie. Untersuchungen zur Kritik der reinen Vernunft. Königstein: Atheneum Verlag.

Baum, M. (1993), 'Metaphysik und Kritik in Kants theoretischer Philosophie', in K. Held and J. Henningfeld (eds), Kategorien der Existenz: Festschrift für Wolfgang Janke. Würzburg: Königshausen \& Neumann: 13-30.

Baumgarten, A. G. (2011), Metaphysica / Metaphysik [1739]. Ed. and trans. by G. Gawlick and L. Kreimendahl. Stuttgart-Bad Cannstatt: Frommann-Holzboog.

Benoist, J. (1996), 'Sur une prétendue ontologie kantienne: Kant et la néo-scolastique', in C. Ramond (ed.), Kant et la pensée moderne: alternatives critiques. Bordeaux: Presses Universitaires de Bordeaux.

Bouton, C. (1996), 'Ontologie et logique dans l'interprétation hégélienne de Christian Wolff, Les études philosophiques 1-2: 241-260.

Courtine, J. F. (1990), Suarez et le système de la métaphysique. Paris: PUF.

Cramer, K. (2001), 'Peripetien der Ontologie - Wolff, Kant, Hegel', in R. Bubner and W. Mesch (eds), Die Weltgeschichte — das Weltgericht? Stuttgart: Klett-Cotta: 176-207.

De Boer, K. (2010a), 'Pure Reason’s Enlightenment: Transcendental Reflection in Kant's First Critique', Kant Yearbook 2: 53-73.

De Boer, K. (2010b), On Hegel: The Sway of the Negative. Basingstoke: Palgrave Macmillan. De Boer, K. (2011), 'Kant, Hegel, and the System of Pure Reason', in E. Ficara (ed.), Die Begründung der Philosophie im Deutschen Idealismus. Würzburg: Königshausen und Neumann.

Demange, D. (2009), 'Métaphysique et théorie de la représentation. La question des origines du transcendentalisme revisitée’, Revue philosophique de Louvain 107(1): 1-21.

Doyle, J. P. (1997), 'Between Transcendental and Transcendent: The Missing Link?', Review of Metaphysics 50: 783-815.

Fulda, H. F. (1988), 'Ontologie nach Kant und Hegel', in D. Henrich and R. P. Horstmann (eds), Metaphysik nach Kant? Stuttgart: Klett-Cotta: 45-80.

Fulda, H. F. (1999), 'Die Ontologie und ihr Schicksal in der Philosophie Hegels. Kantkritik in Fortsetzung kantischer Gedanken', Revue Internationale de Philosophie 53: 465483. 
Grondin, J. (1989), Kant et le problème de la philosophie: l'a priori. Paris: Vrin.

Guyer, P. (1987), Kant and the Claims of Knowledge. Cambridge: Cambridge University Press. Hegel, G. W. F. (1986), Vorlesungen über die Geschichte der Philosophie III [1805-1831], Werke in zwañig Bänden. Ed. by E. Moldenhauer and K. M. Michel. Frankfurt am Main: Suhrkamp. Trans. E. S. Haldane and H. Simson as (1995) Lectures on the History of Philosophy, Vol. 3. Lincoln/London: University of Nebraska Press.

Hegel, G. W. F., Enayklopädie der philosophischen Wissenschaften im Grundrisse I, Werke in zwanzig Bänden. Ed. E. Moldenhauer and K. M. Michel. Frankfurt am Main: Suhrkamp. Trans. W. Wallace as Hegel's Logic (1975). Oxford: Clarendon Press.

Hegel, G. W. F. (1986), Wissenschaft der Logik (2 vols.) [1812-16, 1831], Werke in zwanzig Bänden. Ed. E. Moldenhauer and K. M. Michel. Frankfurt am Main: Suhrkamp. Trans. A. V. Miller as (1997) Hegel's Science of Logic. Amherst, NY: Prometheus Books.

Hinske, N. (1968), 'Die historischen Vorlagen der Kantischen Transzendentalphilosophie', Archiv für Begriffsgeschichte XII: 86-113.

Hinske, N. (1970), Kants Weg zur Transzendentalphilosophie. Stuttgart: Kohlhammer.

Hinske, N. (1973), 'Kants Begriff des Transzendentalen und die Problematik seiner Begriffsgeschichte', Kant-Studien 64(1): 56-62.

Hinske, N. (1998), 'Transzendental — 18 Jh.', in J. Ritter and K. Gründer (eds), Historisches Wörterbuch der Philosophie, Band X. Basel: Schwabe Verlag, 1376-1388.

Honnefelder, L. (1990), Scientia transcendens. Die formale Bestimmung der Seiendheit und Realität in der Metaphysike des Mittelalters und der Neuzeit. Hamburg: Felix Meiner Verlag.

Honnefelder, L. (1995), 'Die “Transzendentalphilosophie der Alten": Zur mittelalterlichen Vorgeschichte von Kants Begriff der Transzendentalphilosophie', Proceedings of the Eighth International Kant Congress, Part I. Milwaukee: Marquette University Press: 394-407.

Kant, I. (1992), 'The Employment in Natural Philosophy of Metaphysics combined with Geometry, of which Sample I Contains the Physical Monadology' [1756], in Theoretical Philosopby 1755-1770, trans. D. Walford. Cambridge: Cambridge University Press.

Kant, I., Kritik der reinen Vernunft [1781/1789]. Hamburg: Meiner. Trans. P. Guyer and A. W. Wood as (1999) Critique of Pure Reason. Cambridge: Cambridge University Press. I have sometimes modified the translation.

Kant, I., Prolegomena zu einer jeden künftigen Metaphysik die als Wissenschaft wird auftreten können [1783]. Hamburg: Meiner. Trans. G. Hatfield as (1997) Prolegomena to Any Future Metaphysics That Will Be Able to Come Forward as Science. Cambridge: Cambridge University Press.

Kant, I., Reflektionen zur Metaphysik, cited after the edition of the Akademie der Wissenschaften, AA 17 and 18. 
Kant, I., Vorlesungen zur Metaphysik, cited after the edition of the Akademie der Wissenschaften, AA 28-29. Partly translated by K. Ameriks and S. Naragon as (2001) Lectures on Metaphysics. Cambridge: Cambridge University Press.

Knittermeyer, H. (1953/54), 'Von der klassischen zur kritischen Transzendentalphilosophie', Kant-Studien 45(1-4): 113-131.

Krouglov, A. N. (2004), 'Der Begriff transzendental bei J. N. Tetens. Historischer Kontext und Hintergründe', in Aufklärung. Interdisziplinäres Jabrbuch zur Erforschung des 18. Jabrbunderts und seiner Wirkungsgeschichte 16: 35-75.

Mabille, B. (2004), Hegel, Heidegger et la métaphysique. Recherches pour une constitution. Paris: Vrin.

Mora, J. F., (1963), 'On the Early History of Ontology', Philosophy and Phenomenological Research 24: 36-47.

Pinder, T. (1986), 'Kants Begriff der transzendentalen Erkenntnis. Zur Interpretation der Definition des Begriffs "transzendental" in der Einleitung zur Kritik der reinen Vernunft', Kant-Studien 77: 1-40.

Pippin, R. (1989), Hegel's Idealism: The Satisfactions of Self-Consciousness. Cambridge: Cambridge University Press.

Pinkard, T. (1979), 'The Logic of Hegel's Logic', Journal of the History of Philosophy 17(4): 417-435.

Ritter J. and K. Gründer (eds) (1998), 'Transzendental; Transzendentalphilosophie', in Historisches Wörterbuch der Philosophie, Band X. Basel: Schwabe Verlag, 1358-1387.

Sala, G. B. (1988), 'Die transzendentale Logik Kants und die Ontologie der Deutschen Schulphilosophie,' Pbilosophisches Jabrbuch 95: 18-53.

Schnepf, R. (2007), 'Metaphysik und Metaphysikkritik in Kants Transzendentalphilosophie', in J. Stolzenberg (ed.), Kant in der Gegenwart. Berlin: Walter de Gruyter: 71-112.

Stern, R. (2009), Hegelian Metaphysics. Oxford: Oxford University Press.

Strawson, P. F. (1966), The Bounds of Sense: An Essay on Immanuel Kant's Critique of Pure Reason. London: Methuen.

Tetens, J. N., Über die allgemeine speculativische Pbilosophie. Philosophische Versuche über die menschliche Natur und ibre Entwicklung, Band I [1775]. Berlin: Reuther und Reichard, 1913.

Vollrath, E. (1962), 'Die Gliederung der Metaphysik in eine metaphysica generalis und eine metaphysica specialis', Zeitschrift für philosophische Forscbung 16(2), 258-284.

Tonelli, G. (1994), Kant's Critique of Pure Reason within the Tradition of Modern Logic: A Commentary on its History. Ed. D. H. Chandler. Hildesheim etc.: Georg Olms Verlag. Wolff, C., Vernünftige Gedancken von Gott, der Welt und der Seele des Menschen, auch allen Dingen überhaupt [1720], Gesammelte Werke I/2. Ed. C. A. Corr. Hildesheim etc.: Georg Olms Verlag, 1983. 
Wolff, C., Discursus Praeliminaris de Philosophia in Genere. Einleitende Abhandlung über Philosophie im allgemeinen [1728]. Trans. and ed. G. Gawlick and L. Kreimendahl. StuttgartBad Cannstatt: Frommann-Holzboog, 1996.

Wolff, C., Philosophia prima sive ontologia / Erste Philosophie oder Ontologie [1729] SS 1-78. Trans. and ed. D. Effertz. Hamburg: Felix Meiner Verlag, 2005.

Wolff, C., Cosmologia Generalis [1731], Gesammelte Werke II/4. Ed. J. École. Hildesheim: Georg Olms Verlag, 1964.

Wolff, C., Ausfübrliche Nacbricht von seinen eigenen Schriften, die er in Deutscher Sprache herausgegeben [1733], Gesammelte Werke I/9. Ed. H. W. Arndt. Hildesheim etc.: Georg Olms Verlag, 1973.

Zöller, G. (2001): “Die Seele des Systems”: Systembegriff und Begriffssystem in Kants Transzendentalphilosophie,' in H. F. Fulda and J. Stolzenberg (eds): Architektonik und System in der Pbilosophie Kants. Hamburg: Felix Meiner Verlag: 54-72. 